\title{
Effects of a combination butaphosphan and cyanocobalamin product and insulin on ketosis resolution and milk production
}

\author{
J. L. Gordon, ${ }^{*}$ T. F. Duffield, ${ }^{* 1}$ T. H. Herdt, † D. F. Kelton, ${ }^{*}$ L. Neuder,† and S. J. LeBlanc ${ }^{*}$ \\ *Department of Population Medicine, University of Guelph, Guelph, ON, N1G 2W1, Canada \\ †Department of Large Animal Clinical Sciences, Michigan State University, East Lansing 48824
}

\begin{abstract}
The objective of this study was to determine the effects of butaphosphan-cyanocobalamin $(\mathrm{B}+\mathrm{C})$, glargine insulin, and propylene glycol on resolution of ketosis and average daily milk yield after treatment. Cows from 16 herds in Ontario, Canada, and 1 herd in Michigan were tested at weekly intervals between 3 and 16 DIM. Ketosis was defined as blood $\beta$-hydroxybutyrate (BHB) $\geq 1.2 \mathrm{mmol} / \mathrm{L}$. All ketotic cows were given a baseline treatment of $3 \mathrm{~d}$ of $300 \mathrm{~g}$ of propylene glycol orally. Animals were then randomly assigned to treatment with 3 doses of either $25 \mathrm{~mL}$ of $\mathrm{B}+\mathrm{C}$ or $25 \mathrm{~mL}$ of saline placebo and 1 dose of either $2 \mathrm{~mL}$ (200 IU) of glargine insulin or $2 \mathrm{~mL}$ of saline placebo in a $2 \times 2$ factorial arrangement. Outcomes of interest on all farms were ketosis cure (blood BHB $<1.2 \mathrm{mmol} / \mathrm{L} 1 \mathrm{wk}$ postenrollment), maintenance of ketosis cure (blood BHB $<1.2$ $\mathrm{mmol} / \mathrm{L} 1$ and 2 wk postenrollment), and blood BHB concentrations at 1 and 2 wk postenrollment. Milk weights were collected daily in 1 large freestall herd. Repeated measures ANOVA was used to evaluate blood BHB concentrations 2 wk after treatment and milk production for $30 \mathrm{~d}$ after treatment. Poisson regression was used to examine the effect of treatment on cure and maintenance of cure. Due to a regulatory delay causing temporary unavailability of $\mathrm{B}+\mathrm{C}$ in Canada, data were analyzed in 2 sets of models: one for insulin and the corresponding placebo $(\mathrm{n}=620)$ and one for the full trial $(\mathrm{n}=380)$. Animals with blood glucose concentrations $\leq 2.2 \mathrm{mmol} / \mathrm{L}$ at the time of ketosis diagnosis were 2.1 times more likely ( $95 \% \mathrm{CI}=1.2$ to 3.7$)$ to be cured if treated with $\mathrm{B}+\mathrm{C}$. Animals in lactation 3 or higher that had blood glucose concentrations $<2.2 \mathrm{mmol} / \mathrm{L}$ at enrollment produced $4.2 \mathrm{~kg} / \mathrm{d}(95 \% \mathrm{CI}=1.4$ to 7.1$)$ more milk if treated with insulin versus placebo and 2.8 $\mathrm{kg} / \mathrm{d}(95 \% \mathrm{CI}=0.9$ to 4.7$)$ more milk if treated with $\mathrm{B}+\mathrm{C}$ versus placebo. Animals in lactation 3 or higher
\end{abstract}

Received August 26, 2016.

Accepted December 27, 2016.

${ }^{1}$ Corresponding author: tduffiel@uoguelph.ca with blood glucose $\geq 2.2 \mathrm{mmol} / \mathrm{L}$ that were treated with insulin produced $2.3 \mathrm{~kg} / \mathrm{d}(95 \% \mathrm{CI}=0.3$ to 4.4$)$ less milk than untreated controls. No interaction was observed between treatments. This evidence suggests that $\mathrm{B}+\mathrm{C}$ and insulin may be beneficial for ketosis treatment in animals with blood glucose $<2.2 \mathrm{mmol} / \mathrm{L}$ at ketosis diagnosis. It also suggests that blood glucose concentration may be an important predictor of success of ketosis treatment.

Key words: ketosis, insulin, cyanocobalamin, propylene glycol

\section{INTRODUCTION}

The transition from the late dry period to early lactation requires a highly orchestrated series of physiological processes to occur to facilitate a smooth start to lactation (Bauman and Currie, 1980). In some animals, proper adaptation does not occur. These animals are prone to metabolic disease, especially hyperketonemia (Herdt, 2000).

Effective treatment of cows with ketosis is challenging. Recently, interest has been renewed in identifying efficacious ketosis treatments. One recent study examined the effects of propylene glycol (PG) treatment and found that treated cows were more likely to resolve ketosis, had increased milk production, and were less likely to have a displaced abomasum (DA) or be culled during the first $30 \mathrm{~d}$ of lactation (McArt et al., 2011, 2012a). This study provided a good base from which to investigate whether additional treatments would further alleviate the negative effects of ketosis.

A combination butaphosphan-cyanocobalamin $(\mathbf{B}+\mathbf{C}$, Catosal, Bayer, Shawnee, KS $)$ product has been investigated for ketosis prevention and treatment (Lohr et al., 2006; Fürll et al., 2010; Rollin et al., 2010). Cyanocobalamin is a form of vitamin $\mathrm{B}_{12}$ that has been shown to be decreased in cows around the time of parturition (Kincaid and Socha, 2007). It has been hypothesized that administration of vitamin $B_{12}$ may increase gluconeogenesis by increasing the activity of methylmalonyl-CoA mutase, a vitamin $\mathrm{B}_{12}$-dependent 
enzyme in the tricarboxylic acid cycle (Kennedy et al., 1990). In combination with folate, vitamin $B_{12}$ also plays an important role in AA synthesis through remethylation of homocysteine to methionine (Preynat et al., 2009a). Methionine is essential for protein synthesis and acts as a source of methyl groups, which are necessary for many pathways in milk protein production. Treatment of first lactation animals with injectable $\mathrm{B}_{12}$ was reported to increase milk production in one study (Girard and Matte, 2005), but not in another (Akins et al., 2013). Butaphosphan, an organic phosphorus source, may contribute to gluconeogenesis (Rollin et al., 2010) because intermediate compounds in gluconeogenesis must be phosphorylated to continue the cycle. However, it is unclear if this form of phosphorus is biologically available to the animal.

Rollin et al. (2010) gave $\mathrm{B}+\mathrm{C}$ on the day of calving and the following day. Treatment with $\mathrm{B}+\mathrm{C}$ significantly reduced the odds of development of subclinical ketosis development in cows in third lactation or greater, but it had no effect in younger animals. A German study examined the effects of $\mathrm{B}+\mathrm{C}$ when it was administered to cows with a DA and reported that treated cows had an increase in rumination compared with untreated cows (Lohr et al., 2006). However, these data were collected subjectively and the clinical and economic importance of these outcomes is unclear. Butaphosphan-cyanocobalamin has never been used in a large-scale clinical trial for the treatment of subclinical ketosis.

Insulin might be useful in ketosis treatment by suppressing fat mobilization and slowing the production of ketone bodies (Hayirli, 2006). Secretion of insulin is decreased in dairy cattle postpartum (Weber et al., 2016). Tissue insulin responsiveness also decreases around the time of parturition to spare glucose for milk production (Hayirli, 2006). This decrease in responsiveness to insulin is exacerbated by the presence of ketone bodies in the blood (Sakai et al., 1993). Robertson (1966) found that the addition of insulin to steroid administration for treatment of ketosis increased milk production and improved appetite in treated animals over 5 d. Sakai et al. (1993) compared the effects of intravenous glucose in conjunction with subcutaneous insulin compared with glucose treatment alone and found that the addition of insulin decreased blood ketones and increased blood glucose. Seifi et al. (2007) reported that animals treated with insulin were more likely to develop ketosis and treated animals that were subclinically ketotic at time of enrollment were less likely to experience ketosis resolution than untreated animals. However, the animals treated in this study were not given a glucose source in conjunction with the administration of the insulin. Use of insulin in ketosis treatment is uncom- mon, likely due to the risk of severe hypoglycemia if administered without a glucose source (Hayirli, 2006).

The purpose of this study was to examine the effects of $\mathrm{B}+\mathrm{C}$ and insulin administration, with concurrent PG treatment, on subclinical ketosis cure, blood BHB following treatment, and early lactation milk production.

\section{MATERIALS AND METHODS}

\section{Study Population}

Data were collected from 16 dairy herds in Ontario (farms A through P) and 1 dairy herd in Michigan (farm Z) from May 13 to September 14, 2011. Herds were purposively selected based on their proximity to study sites and willingness to comply with the proposed ketosis testing and treatment protocol. To be eligible for enrollment, herds were required to be enrolled in monthly milk testing through a DHI organization or collect daily milk weights on farm. Enrolled herds included tie-stall- $(\mathrm{n}=8)$ and freestall-housed herds $(\mathrm{n}=$ 8) ranging in size from 50 to 3,200 lactating animals. In all herds, a TMR was fed to all lactating cattle.

\section{Data Collection and Study Design}

Herds were visited weekly on the same day of the week and at approximately the same time of day throughout the study period. All cows 3 to 16 DIM were tested for ketosis using the Precision Xtra meter (Abbott Laboratories, Abbott Park, IL). Ketosis was defined a priori as $\mathrm{BHB} \geq 1.2 \mathrm{mmol} / \mathrm{L}$. The Precision Xtra meter is a handheld device that measures BHB in whole blood. This meter has been previously validated for use in cattle and has a reported sensitivity of $88 \%$ and a specificity of $96 \%$ at this cut point (Iwersen et al., 2009). Cows were excluded from testing if they had been previously diagnosed with ketosis or a DA by farm personnel during the current lactation or had been enrolled in the study the previous week. Animals were not observed for clinical signs of ketosis by study personnel, so no determinations on clinical ketosis status could be made. This testing scheme provided 2 opportunities for enrollment for each animal, once at 3 to 9 DIM and once at 10 to 16 DIM.

Blood was drawn from the coccygeal vessels using a 20-gauge, $2.54-\mathrm{cm}$ needle and 3 - $\mathrm{mL}$ syringe. Ketone testing was performed immediately after blood collection according to the manufacturer's instructions. In animals that were classified as ketotic, blood glucose concentrations were also measured using a second Precision Xtra test. Blood was tested for glucose immediately after the ketone results were displayed. The 
procedure for glucose testing is the same as for ketone testing, except that the results are displayed in $5 \mathrm{~s}$. The use of Precision Xtra for glucose determination has also been validated in dairy cattle (Wittrock et al., 2013).

All animals classified as ketotic $(\geq 1.2 \mathrm{mmol} / \mathrm{L}$ of blood BHB) were treated with $300 \mathrm{~g}$ of $\mathrm{PG}$ per day for $3 \mathrm{~d}$ via oral drench. The concentration of $\mathrm{PG}$ in the drench varied by study site, so animals were treated with $450 \mathrm{~mL}$ of liquid (67\% PG, Glycol-P, Vetoquinol, Lavaltrie, QC, Canada) in Ontario herds and $300 \mathrm{~mL}$ of liquid in the Michigan herd. Additional treatment with $25 \mathrm{~mL}$ of $\mathrm{B}+\mathrm{C}$ or $25 \mathrm{~mL}$ of saline placebo subcutaneously for 3 consecutive days and $2 \mathrm{~mL}$ (200 IU) of insulin glargine (Lantus, Sanofi-Aventis, Laval, QC, Canada) or $2 \mathrm{~mL}$ of saline placebo subcutaneously once at the time of enrollment were applied in a $2 \times$ 2 factorial arrangement. These doses were selected for convenience and to provide consistency between study sites. Subcutaneous injections were split so a maximum of $10 \mathrm{~mL}$ was administered per site. Randomization was performed using a random number generator so that sequential blocks of 4 cows included one of each treatment combination. In the Michigan herd, treatments were randomized separately for primiparous and multiparous animals. In Ontario herds, all animals were included on the same randomization list. Individuals performing the testing, assigning the treatment group, and administering treatments, farm personnel, and veterinarians were blinded to $\mathrm{B}+\mathrm{C}$ and insulin treatment.

Enrolled cows were tested for blood BHB and glucose concentrations at weekly intervals for 2 wk after treatment. Further data collected included lactation number, DIM at enrollment, and (at farm Z only) daily milk weights. Milk weights were exported from DairyComp 305 daily throughout the study period. Milk weights recorded as 0 were re-entered as missing data points. Animals were excluded from analysis if they did not receive the assigned treatments, were not tested at 1 and 2 wk after treatment, or died or were sold before 2 wk after treatment. Animals were excluded from daily milk yield analysis if they did not have at least 10 daily milk weights during the study period.

The personnel responsible for the health of the animals on the farm were allowed to treat enrolled animals for other disease conditions as needed. They were asked to record any treatments given and this was included in the analysis. Study personnel asked herd owners and workers about the treatment status of all enrolled animals on a weekly basis.

This study aimed to screen 1,600 cows. With an expected ketosis incidence rate of $20 \%$, this would yield 320 cows with ketosis and 80 cows per treatment group. Given $95 \%$ confidence, $80 \%$ power, and $0.45 \mathrm{mmol} / \mathrm{L}$ standard deviation, this sample size would allow for detection of a $0.2 \mathrm{mmol} / \mathrm{L}$ difference in blood BHB between treatment groups. This study was reviewed and approved by the University of Guelph Animal Care Committee (11R036) and the Michigan State University Institutional Animal Care and Use Committee (\#04/11-078-00).

There was a period of unavailability of $\mathrm{B}+\mathrm{C}$ in Ontario during most of the study due to a regulatory approval delay. During this period, the randomization specified above was maintained except that the animals were treated with only insulin or the corresponding placebo. Thus, each sequential block of 4 animals would include 2 treated with insulin and 2 treated with placebo. No placebo for $\mathrm{B}+\mathrm{C}$ was given to these animals to prevent unnecessary discomfort. Due to the length of the approval delay, an insufficient number of animals were treated with $\mathrm{B}+\mathrm{C}$ in Ontario herds. All analysis of $\mathrm{B}+\mathrm{C}$ was completed using data from one large herd (farm Z). Analysis of insulin included data from all herds where at least 8 animals were enrolled in the study (4 blocks of treatment with insulin and placebo). Herds with fewer than 8 animals enrolled were excluded from analysis.

\section{Statistical Analysis}

All statistical analyses were performed in SAS (version 9.3, SAS Institute Inc., Cary, NC). The outcomes of interest were ketosis cure at 1 wk posttreatment, maintenance of ketosis cure at the second week posttreatment, blood BHB concentrations at 1 and 2 wk posttreatment, and average daily milk production in the first $30 \mathrm{~d}$ after treatment. Ketosis cure and numerical decrease of $\mathrm{BHB}$ were both of interest. Ketosis cure is a measure of whether or not the blood BHB of an animal dropped below a predefined cut point during the specified time period, but it does not capture the amount the blood BHB decreased after treatment. Animals with high blood BHB at the time of enrollment may have a large decrease in blood BHB after treatment, but may not drop below the cut point. This decrease may still be important to health and production. Separate models were constructed for the full trial $(\mathrm{B}+\mathrm{C}$ and insulin) and the insulin trial. Ketosis cure was defined as blood BHB concentrations $<1.2 \mathrm{mmol} / \mathrm{L}$ at 1 wk posttreatment. Maintenance of cure was defined as blood BHB concentrations $<1.2 \mathrm{mmol} / \mathrm{L}$ at 1 and 2 wk posttreatment. Continuous variables (DIM at enrollment, BHB, and glucose at all 3 time points) were examined for normality. The DIM was right skewed and was categorized in 2 ways based on previous literature (Duffield et al., 2009; McArt et al., 2012b), enrollment at wk 1 (3 to 9 DIM) versus wk 2 (10 to 16 DIM), and early (3 to 5 DIM) versus late (6 to 16 DIM). Glucose was 
categorized into $\geq 2.2$ and $<2.2 \mathrm{mmol} / \mathrm{L}$ (low) based on sensitivity analysis and was offered to models in 2 ways, as either a linear or categorical predictor. A natural log-transformation was used to normalize BHB values 1 and 2 wk posttreatment. An appropriate transformation could not be found for enrollment BHB concentration, so it was categorized into moderate (1.2 to 2.4 $\mathrm{mmol} / \mathrm{L})$ and high $(\geq 2.4 \mathrm{mmol} / \mathrm{L})$ based on sensitivity analysis. Parity groups were set as 1,2 , and $\geq 3$ lactations. Descriptive statistics were generated with PROC FREQ and PROC MEANS in SAS. All variables were examined for association with the selected outcomes using contingency tables and the chi-squared statistic using PROC GLM. Any variable with a univariable association with the outcome $(P \leq 0.2)$ was offered for inclusion in multivariable models.

For the outcomes cure and maintenance of cure, Poisson regression was used (PROC GENMOD in SAS), with a log link and Poisson distribution with no offset. Clustering by herd and overdispersion were accounted for in the model with an exchangeable correlation structure. This type of model was used to allow for the associations to be expressed as risk ratios (RR) rather than odds ratios (Ospina et al., 2012). Risk ratios report probabilities directly, are easier to interpret, and are less likely to overestimate the true effect when outcomes of interest are common (Ospina et al., 2012). Mixed models (PROC MIXED in SAS) were used to examine the effects of treatment on BHB concentrations 1 and 2 wk posttreatment and average daily milk production in the first $30 \mathrm{~d}$ after treatment with cow as a repeated measure and a first-order autoregressive correlation structure. Numerous correlation structures for the herd effect were examined, and the model with the lowest Akaike information criterion was selected.

Correlation between variables was determined using PROC CORR of SAS, with variables considered to be collinear if their Pearson correlation coefficient was $\geq 0.3$. All variables with a univariable association with the outcome $(P \leq 0.2)$ were offered to the respective multivariable models, which were built manually using a backward stepwise elimination process. The variable with the highest $P$-value was removed until only variables significantly associated with the outcome $(P \leq 0.05)$ remained in the model. Treatments $(\mathrm{B}+\mathrm{C}$ and insulin) were retained in all of the applicable models regardless of $P$-value. Each model was examined for evidence of confounding (changes in coefficients of the final model by $>20 \%$ ) at the removal of each variable. Biologically relevant interaction terms were formed between variables in the final model and retained if significant $(P \leq$ 0.05 ). If both the continuous and dichotomized form of a predictor variable were significantly associated with an outcome in univariable analysis, they were tested in separate backward stepwise multivariable models and the form of the predictor in the model with the lowest Akaike information criterion was selected. If treatment was part of a significant interaction with another predictor, the outcome was stratified by the predictor and stratum specific results were presented. Effects of $\mathrm{B}+\mathrm{C}$, insulin, and possible interactions between the 2 were examined using data from 380 cows in one herd (farm Z). No interaction was observed between B+C and insulin in these models, so models for the effects of insulin alone were constructed using data from all herds with at least 8 animals enrolled.

Milk models were examined in 2 ways, all animals included or animals treated with the opposite treatment excluded (i.e., $\mathrm{B}+\mathrm{C}$ versus control, with insulin and $\mathrm{B}+\mathrm{C}$ and insulin cows excluded). This was to ensure that the effects of 1 treatment were not masking the effects of the opposite treatment. The analysis was conducted in this manner despite the fact that the interaction between the 2 treatments was not significant in any model, including the milk models $(P=0.6$ to 0.9$)$.

\section{RESULTS}

\section{Descriptive Statistics}

Of the 1,653 animals tested, $712(43 \%)$ were classified as ketotic (blood BHB $\geq 1.2 \mathrm{mmol} / \mathrm{L}$ ). Due to labor constraints, there was a maximum number of animals that could be enrolled per farm per week, so 14 of these animals were not enrolled. Of the 698 animals enrolled, 42 were excluded because they did not receive the full course of treatment $(\mathrm{n}=6)$, were enrolled twice $(\mathrm{n}=$ 1 ), were not tested at 1 and 2 wk posttreatment $(\mathrm{n}=$ $19)$, died or were euthanized $(\mathrm{n}=12)$, or were sold ( $\mathrm{n}$ $=4$ ) before the end of the study period. Six farms had less than 8 animals enrolled (farms C, E, G, H, I, and $\mathrm{O})$, so animals from these herds were removed from analysis $(\mathrm{n}=36)$.

The cumulative lactational incidence for ketosis in the study was $43 \%$, but the herd incidence ranged from $20 \%$ (farm L) to $79 \%$ (farm P). Seven of the 11 herds had a cumulative lactation incidence of more than $40 \%$. Herd lactational incidence risk had no effect on ketosis cure or blood BHB concentrations after treatment.

Descriptive statistics for the 620 animals enrolled in the insulin study are provided in Table 1 . The control group was composed of 57, 99, and 160 animals in lactation 1,2 , and $\geq 3$, respectively. The insulin group was composed of 50, 95, and 159 animals in lactation 1, 2, and $\geq 3$, respectively. No differences $(P=0.7$ to 0.9$)$ were present in lactation number, DIM at enrollment, or enrollment BHB concentration between treatment groups. 
Table 1. Descriptive statistics by treatment group for 620 animals enrolled in a ketosis treatment trial utilizing insulin glargine (Lantus, Sanofi-Aventis, Laval, QC, Canada)

\begin{tabular}{lcc}
\hline & $\begin{array}{c}\text { Control } \\
(\mathrm{n}=316)\end{array}$ & $\begin{array}{c}\text { Insulin } \\
(\mathrm{n}=304)\end{array}$ \\
\hline Item & & \\
BHB (mmol/L, mean $\pm \mathrm{SD})$ & $2.4 \pm 1.4$ & $2.3 \pm 1.1$ \\
Enrollment & 68 & 68 \\
$\%$ BHB 1.2 to 2.4 & 32 & 32 \\
$\%$ BHB $>2.4$ & $2.0 \pm 1.5$ & $1.8 \pm 1.3$ \\
Wk +1 & 38 & 42 \\
$\%$ BHB $\leq 1.2$ & 31 & 31 \\
$\%$ BHB 1.2 to 2.4 & 31 & 28 \\
$\%$ BHB $\geq 2.4$ & $1.7 \pm 1.3$ & $1.8 \pm 1.4$ \\
Wk +2 & 43 & 46 \\
$\%$ BHB $\leq 1.2$ & 33 & 29 \\
$\%$ BHB 1.2 to 2.4 & 24 & 25 \\
$\%$ BHB $\geq 2.4$ & 67 & 74 \\
Maintenance of cure & & \\
Glucose (mmol/L, mean \pm SD) & $2.3 \pm 0.7$ & $2.3 \pm 0.6$ \\
Enrollment & 44 & 44 \\
$\%<2.2$ mmol/L & $2.6 \pm 0.7$ & $2.6 \pm 0.7$ \\
Wk +1 & $2.8 \pm 0.7$ & $2.8 \pm 0.7$ \\
Wk +2 & &
\end{tabular}

Descriptive statistics for the 380 animals enrolled in the full trial are provided in Table 2 . The control group was composed of 15,29 , and 55 animals in lactation 1,2 , and $\geq 3$, respectively. The insulin group was composed of 15,30 , and 51 animals in lactation 1,2 , and $\geq 3$, respectively. The $\mathrm{B}+\mathrm{C}$ group was composed of 13,35 , and 48 animals in lactation 1,2 , and $\geq 3$, respectively. The insulin $+\mathrm{B}+\mathrm{C}$ group was composed of 14,28 , and 47 animals in lactation 1,2 , and $\geq 3$, respectively. No differences $(P=0.8$ to 0.9$)$ were present in lactation number, DIM at enrollment, or enrollment BHB concentration between treatment groups. No adverse reactions to either treatment occurred.

\section{Insulin Study}

Effect of Insulin Treatment on Ketosis Cure. Cure risk was $42 \%(\mathrm{n}=127)$ for cows treated with insulin and 38\% ( $\mathrm{n}=120)$ for controls. Based on significant associations in the univariable analysis, variables offered to the insulin model for ketosis cure risk included parity $(P=0.004)$, enrollment BHB category $(P<0.0001)$, glucose category $(P=0.004)$, and insulin treatment $(P=0.8) . \beta$-Hydroxybutyrate $>2.4 \mathrm{mmol} / \mathrm{L}$, low enrollment glucose, and increased parity were all significantly associated with decreased ketosis cure (Table 3). Insulin treatment was not associated with ketosis cure. No significant interactions were present between model variables.

Effect of Insulin Treatment on Maintenance of Ketosis Cure. A total of 247 animals were classified as cured and could be used in the maintenance of cure model. The risk of maintenance of cure was $74 \%$ $(\mathrm{n}=94)$ for animals treated with insulin and $67 \%(\mathrm{n}=$ 80) for control animals. Variables offered to the insulin model for maintenance of ketosis cure included parity $(P=0.004)$ and insulin treatment $(P=0.2)$. After accounting for parity, no effect was observed of insulin on maintenance of ketosis cure $(\mathrm{RR}=1.0,95 \% \mathrm{CI}=$ 0.9 to $1.2, P=0.1$ ).

Effect of Insulin Treatment on Blood BHB Concentrations. Variables offered to the models to examine the effect of treatment on blood BHB concentration 1 and 2 wk after treatment included parity

Table 2. Descriptive statistics by treatment group for 380 animals enrolled in a ketosis treatment trial utilizing $10 \%$ butaphosphan-cyanocobalamin (B+C, Catosal, Bayer, Shawnee, KS) and insulin glargine (Lantus, SanofiAventis, Laval, QC, Canada)

\begin{tabular}{|c|c|c|c|c|}
\hline Item & $\begin{array}{l}\text { Control } \\
(\mathrm{n}=99)\end{array}$ & $\begin{array}{c}\mathrm{B}+\mathrm{C} \\
(\mathrm{n}=95)\end{array}$ & $\begin{array}{l}\text { Insulin } \\
(\mathrm{n}=96)\end{array}$ & $\begin{array}{c}\text { Both } \\
(\mathrm{n}=90)\end{array}$ \\
\hline \multicolumn{5}{|l|}{$\mathrm{BHB}(\mathrm{mmol} / \mathrm{L}$, mean $\pm \mathrm{SD})$} \\
\hline Enrollment & $2.2 \pm 1.1$ & $2.4 \pm 1.3$ & $2.3 \pm 1.1$ & $2.1 \pm 1.0$ \\
\hline$\%$ BHB 1.2 to 2.4 & 70 & 66 & 66 & 73 \\
\hline$\%$ BHB $\geq 2.4$ & 30 & 34 & 34 & 27 \\
\hline $\mathrm{Wk}+1$ & $1.9 \pm 1.4$ & $1.8 \pm 1.5$ & $1.9 \pm 1.3$ & $1.7 \pm 1.4$ \\
\hline$\%$ BHB $\leq 1.2$ & 28 & 36 & 40 & 48 \\
\hline$\%$ BHB $\overline{1} .2$ to 2.4 & 44 & 34 & 33 & 36 \\
\hline$\% \mathrm{BHB} \geq 2.4$ & 28 & 30 & 27 & 16 \\
\hline $\mathrm{Wk}+2$ & $1.6 \pm 1.2$ & $1.6 \pm 1.1$ & $1.7 \pm 1.3$ & $1.9 \pm 1.5$ \\
\hline$\%$ BHB $\leq 1.2$ & 44 & 43 & 46 & 50 \\
\hline$\%$ BHB 1.2 to 2.4 & 33 & 35 & 29 & 27 \\
\hline$\% \mathrm{BHB} \geq 2.4$ & 23 & 22 & 25 & 23 \\
\hline Maintenance of cure & 88 & 70 & 91 & 70 \\
\hline \multicolumn{5}{|c|}{ Glucose $(\mathrm{mmol} / \mathrm{L}$, mean $\pm \mathrm{SD})$} \\
\hline $\begin{array}{l}\text { Enrollment } \\
\% \text { glucose }<2.2 \mathrm{mmol} / \mathrm{L}\end{array}$ & $\begin{array}{l}2.3 \pm 0.5 \\
\quad 46\end{array}$ & $\begin{array}{l}2.3 \pm 0.6 \\
42\end{array}$ & $\begin{array}{l}2.4 \pm 0.6 \\
45\end{array}$ & $\begin{array}{l}2.3 \pm 0.6 \\
44\end{array}$ \\
\hline $\mathrm{Wk}+1$ & $2.7 \pm 0.7$ & $2.7 \pm 0.7$ & $2.8 \pm 0.7$ & $2.7 \pm 0.7$ \\
\hline $\mathrm{Wk}+2$ & $2.9 \pm 0.7$ & $3.0 \pm 0.7$ & $2.8 \pm 0.7$ & $2.8 \pm 0.7$ \\
\hline
\end{tabular}


$(P<0.0001)$, enrollment BHB category $(P<0.0001)$, glucose category $(P=0.004)$, and insulin treatment $(P$ $=0.5$ ). Multiparous cows had significantly higher blood BHB concentrations at 1 and 2 wk posttreatment $(P=$ 0.0003 and $P<0.0001$, respectively). Higher blood BHB concentrations and lower blood glucose concentrations at enrollment were also associated with significantly higher blood $\mathrm{BHB}$ concentrations at 1 and 2 wk posttreatment $(P=0.0009$ to 0.01$)$. Insulin had no effect on blood BHB concentrations at either time point $(P=$ 0.2 and 0.8 ). No significant interactions were observed among model variables.

\section{Full Trial}

Effect of Treatment on Ketosis Cure. Variables offered to the model for ketosis cure included parity $(P=0.0001)$, enrollment BHB category $(P=0.0007)$, early enrollment (3 to 5 DIM, $P=0.02)$, glucose category $(P<0.0001)$, $\mathrm{B}+\mathrm{C}$ treatment $(P=0.2)$, and insulin treatment $(P=0.9)$. Animals with a higher blood BHB at enrollment, those enrolled in the first 3 to $5 \mathrm{~d}$ of lactation, and multiparous animals were less likely to be cured (Table 4). A significant interaction was observed between $\mathrm{B}+\mathrm{C}$ and glucose category, so a stratified analysis was performed (Table 5 ). Cows that had blood glucose $<2.2 \mathrm{mmol} / \mathrm{L}$ at enrollment were significantly more likely to be cured if they were treated with $\mathrm{B}+\mathrm{C}(P=0.02)$. However, $\mathrm{B}+\mathrm{C}$ had no effect on cure risk in animals that had blood glucose $\geq 2.2$ $\mathrm{mmol} / \mathrm{L}$ at enrollment $(\mathrm{RR}=1.0)$. No other significant interactions were present in the model, including between treatments $(P=0.8)$.
Effect of Treatment on Maintenance of Ketosis Cure. One hundred fifty-two animals were categorized as cured and were used for analysis of maintenance of cure. Variables offered to the model for the maintenance of ketosis cure were parity $(P<0.0001)$, enrollment BHB $(P=0.1)$ and glucose $(P=0.0008)$ categories, $\mathrm{B}+\mathrm{C}$ treatment $(P=0.9)$, and insulin treatment $(P=$ $0.5)$. Parity was the only significant predictor of maintenance of ketosis cure with animals in the third and higher lactation being less likely to remain cured than primiparous animals ( $\mathrm{RR}=0.7,95 \% \mathrm{CI}=0.5$ to $0.9, P$ $=0.01)$. Accounting for parity, neither treatment had an effect on maintenance of cure $(\mathrm{B}+\mathrm{C}: \mathrm{RR}=1.1,95 \%$ $\mathrm{CI}=0.9$ to $1.3, P=0.9$ and insulin: $\mathrm{RR}=0.9,95 \%$ CI 0.7 to $1.1, P=0.7)$. No significant interactions were observed among model variables, including between treatments $(P=0.7)$.

Effect of Treatment on Blood BHB Concentrations. Variables offered to the model to examine the effect of treatment on blood BHB concentration 1 wk after treatment included parity $(P<0.0001)$, enrollment BHB category $(P<0.0001), \mathrm{B}+\mathrm{C}$ treatment $(P=0.2)$, and insulin treatment $(P=0.9)$. Variables offered to the model to examine the effect of treatment on blood BHB concentrations 2 wk after treatment included parity $(P<0.0001)$, enrollment BHB category $(P=0.005)$, glucose category $(P<0.0001)$, $\mathrm{B}+\mathrm{C}$ treatment $(P=0.5)$, and insulin treatment $(P=$ $0.5)$. Neither treatment had any effect on blood BHB concentrations at either time point $(\mathrm{B}+\mathrm{C}: \mathrm{wk}+1, P$ $=0.2$; wk $+2, P=0.5$ and insulin: week $+1, P=$ 0.9 ; wk $+2, P=0.1$ ). No significant interactions were present among model variables, including between

Table 3. Final Poisson regression model of ketosis cure in 620 Holsteins from 11 herds $^{1}$

\begin{tabular}{|c|c|c|c|c|c|}
\hline Variable & $\beta$ & SE & $P$-value & $\mathrm{RR}^{2}$ & $95 \%$ CI \\
\hline Intercept & -0.39 & 0.07 & - & - & - \\
\hline \multicolumn{6}{|l|}{ Enrollment BHB } \\
\hline 1.2 to $2.4 \mathrm{mmol} / \mathrm{L}$ & $ـ^{3}$ & - & - & - & - \\
\hline$>2.4 \mathrm{mmol} / \mathrm{L}$ & -0.43 & 0.10 & $<0.0001$ & 0.7 & 0.5 to 0.8 \\
\hline \multicolumn{6}{|l|}{ Glucose at enrollment } \\
\hline$<2.2 \mathrm{mmol} / \mathrm{L}$ & -0.32 & 0.09 & 0.0006 & 0.7 & 0.6 to 0.9 \\
\hline$\geq 2.2 \mathrm{mmol} / \mathrm{L}$ & $ـ^{3}$ & - & - & - & - \\
\hline \multicolumn{6}{|l|}{ Parity } \\
\hline 1 & $ـ^{3}$ & - & - & - & - \\
\hline 2 & -0.34 & 0.12 & $<0.0001$ & 0.7 & 0.6 to 0.9 \\
\hline $3+$ & -0.53 & 0.12 & $<0.0001$ & 0.6 & 0.5 to 0.7 \\
\hline \multicolumn{6}{|l|}{ Insulin treatment } \\
\hline Yes & 0.09 & 0.08 & 0.2 & 1.1 & 0.9 to 1.3 \\
\hline No & -3 & - & - & - & - \\
\hline \multicolumn{6}{|c|}{$\begin{array}{l}{ }^{1} \text { Cows were randomly assigned to treatment with } 200 \mathrm{IU} \text { of insulin glargine (Lantus, Sanofi-Aventis, Laval, } \\
\text { QC, Canada) subcutaneously once }(\mathrm{n}=304) \text { or placebo }(\mathrm{n}=316) \text { at ketosis diagnosis between } 3 \text { and } 16 \text { DIM. } \\
\text { Ketosis was defined as blood } \mathrm{BHB} \geq 1.2 \mathrm{mmol} / \mathrm{L} \text {, and cure was defined as blood } \mathrm{BHB}<1.2 \mathrm{mmol} / \mathrm{L} 1 \text { wk after } \\
\text { treatment. }\end{array}$} \\
\hline
\end{tabular}


Table 4. Final Poisson regression model variables used to predict ketosis cure in 380 Holsteins from one herd ${ }^{1}$

\begin{tabular}{|c|c|c|c|c|c|}
\hline Variable & $\beta$ & SE & $P$-value & $\mathrm{RR}^{2}$ & $95 \% \mathrm{CI}$ \\
\hline Intercept & -0.001 & 0.20 & 0.8 & - & - \\
\hline \multicolumn{6}{|l|}{ BHB at enrollment } \\
\hline 1.2 to $2.4 \mathrm{mmol} / \mathrm{L}$ & $\underline{3}^{3}$ & - & - & - & - \\
\hline$>2.4 \mathrm{mmol} / \mathrm{L}$ & -0.55 & 0.19 & 0.004 & 0.6 & 0.4 to 0.8 \\
\hline \multicolumn{6}{|l|}{ DIM at enrollment } \\
\hline 3 to $5 \mathrm{~d}$ & -0.35 & 0.15 & 0.02 & 0.7 & 0.5 to 0.9 \\
\hline 6 to $16 \mathrm{~d}$ & ${ }^{3}$ & - & - & - & - \\
\hline \multicolumn{6}{|l|}{ Glucose at enrollment } \\
\hline$<2.2 \mathrm{mmol} / \mathrm{L}$ & -0.34 & 0.16 & 0.04 & 0.7 & 0.5 to 1.0 \\
\hline$\geq 2.2 \mathrm{mmol} / \mathrm{L}$ & ${ }^{3}$ & - & - & - & - \\
\hline \multicolumn{6}{|l|}{ Parity } \\
\hline 1 & $-^{3}$ & - & - & - & - \\
\hline 2 & -0.46 & 0.17 & 0.002 & 0.6 & 0.4 to 0.9 \\
\hline $3+$ & -0.49 & 0.16 & 0.002 & 0.6 & 0.4 to 0.8 \\
\hline \multicolumn{6}{|l|}{ Insulin } \\
\hline Yes & -0.002 & 0.13 & 0.9 & 1.0 & 0.8 to 1.3 \\
\hline No & $-^{3}$ & - & - & - & - \\
\hline \multicolumn{6}{|l|}{$\mathrm{B}+\mathrm{C}$} \\
\hline Yes & 0.33 & 0.15 & 0.03 & 1.3 & 1.1 to 1.9 \\
\hline No & $-^{3}$ & - & - & - & - \\
\hline $\mathrm{B}+\mathrm{C} \times$ glucose category & & & 0.02 & & \\
\hline
\end{tabular}

${ }^{1}$ Cows were randomly assigned to treatment with $10 \%$ butaphosphan-cyanocobalamin $(\mathrm{B}+\mathrm{C}$, Catosal, Bayer, Shawnee, KS; $\mathrm{n}=95)$, insulin $(\mathrm{n}=96), \mathrm{B}+\mathrm{C}$ and insulin $(\mathrm{n}=90)$, or control $(\mathrm{n}=99)$ at ketosis diagnosis between 3 and 16 DIM. Ketosis was defined as blood BHB $\geq 1.2 \mathrm{mmol} / \mathrm{L}$ and cure was defined as blood BHB $<1.2 \mathrm{mmol} / \mathrm{L} 1 \mathrm{wk}$ after treatment.

${ }^{2} \mathrm{RR}=$ risk ratio.

${ }^{3}$ Reference group.

treatments $(P=0.8)$. Multiparous cows and cows with enrollment BHB concentrations $\geq 2.4 \mathrm{mmol} / \mathrm{L}$ had significantly increased blood BHB concentrations at 1 wk posttreatment $(P<0.0001)$. Multiparous cows also had significantly increased blood BHB concentrations at 2 wk posttreatment $(P<0.0001)$, though enrollment BHB category was not associated with increased BHB concentrations at this time point $(P=0.1)$. Low glucose at enrollment was associated with increased blood BHB concentrations at 2 wk posttreatment $(P=$ 0.01 ), but not with blood BHB concentrations at $1 \mathrm{wk}$ posttreatment $(P=0.1)$.

Effect of Treatment on Early Lactation Milk Production. A treatment by parity interaction was identified for the effect of treatment on milk production, so a model for milk production was constructed for each parity group. No difference was present among the models, except for parity $3+$ animals in which covariates in the model remained the same but treatment variables and their interactions differed. Treatment effects are thus given from 2 models comparing treated $(\mathrm{B}+\mathrm{C}$ or insulin) to control (no treatment) animals.

Variables offered to the model for effect of treatment on milk production in first lactation animals included month of calving $(P=0.0004)$, early enrollment $(P$ $=0.0007)$, enrollment glucose group $(P=0.1), \mathrm{B}+\mathrm{C}$ treatment $(P=0.06)$, and insulin treatment $(P=$ 0.001, Table 6 ). Early enrollment was associated with significantly decreased average daily milk production $(P=0.0005)$. Milk production was affected by month of calving, though the significance of this effect varied by month $(P=0.2$ to 0.0006$)$. Butaphosphan-cyanocobalamin had no effect on milk production $(P=0.5)$, but treatment with insulin increased milk production by $3.8 \mathrm{~kg} / \mathrm{d}(95 \% \mathrm{CI}=2.1$ to 5.5$)$. No interactions were present between variables.

Variables offered to the model for milk production in second lactation animals included month of calving $(P$ $<0.0001)$, early enrollment $(P<0.0001)$, enrollment BHB group $(P<0.0001), \mathrm{B}+\mathrm{C}$ treatment $(P=0.1)$, and insulin treatment $(P=0.4)$. Neither treatment had any significant effect on production in second lactation animals $(P=0.5)$.

For third and greater lactation animals, variables offered to the model for milk production included month of calving $(P<0.0001)$, early enrollment $(P<0.0001)$, enrollment BHB group $(P<0.0001)$, enrollment glucose group $(P=0.05), \mathrm{B}+\mathrm{C}$ treatment $(P=0.01)$, and insulin treatment $(P=0.2)$. A significant interaction was present between glucose group and both insulin and $\mathrm{B}+\mathrm{C}$. When evaluated based on glucose category at enrollment, animals with low blood glucose at enrollment had a significant increase in production when treated with either $\mathrm{B}+\mathrm{C}(2.8 \mathrm{~kg} / \mathrm{d})$ or insulin $(4.2 \mathrm{~kg} / \mathrm{d}$, Table 7$)$. However, $\mathrm{B}+\mathrm{C}$ had no effect on animals with blood glucose $\geq 2.2 \mathrm{mmol} / \mathrm{L}$ at enrollment 
Table 5. Stratum-specific Poisson models of ketosis cure in Holstein dairy cows with blood glucose $\geq 2.2$ $\mathrm{mmol} / \mathrm{L}(\mathrm{n}=237)$ or $<2.2 \mathrm{mmol} / \mathrm{L}(\mathrm{low}, \mathrm{n}=143)$ at enrollment ${ }^{1}$

\begin{tabular}{|c|c|c|c|c|c|}
\hline Variable & $\beta$ & $\mathrm{SE}$ & $P$-value & $\mathrm{RR}^{2}$ & $95 \% \mathrm{CI}$ \\
\hline \multicolumn{6}{|l|}{ Glucose at enrollment $<2.2 \mathrm{mmol} / \mathrm{L}$} \\
\hline Intercept & -0.85 & 0.46 & 0.07 & - & - \\
\hline \multicolumn{6}{|l|}{ Enrollment BHB } \\
\hline 1.2 to $2.4 \mathrm{mmol} / \mathrm{L}$ & $-^{3}$ & - & - & - & - \\
\hline$>2.4 \mathrm{mmol} / \mathrm{L}$ & -0.44 & 0.29 & 0.1 & 0.6 & 0.4 to 1.1 \\
\hline \multicolumn{6}{|l|}{ DIM at enrollment } \\
\hline 3 to $5 \mathrm{~d}$ & $-^{3}$ & - & - & - & - \\
\hline 6 to $16 \mathrm{~d}$ & -0.12 & 0.38 & 0.8 & 0.9 & 0.5 to 1.7 \\
\hline \multicolumn{6}{|l|}{ Parity } \\
\hline 1 & $-^{3}$ & - & - & - & - \\
\hline 2 & -0.57 & 0.46 & 0.2 & 0.6 & 0.2 to 1.4 \\
\hline $3+$ & -0.83 & 0.45 & 0.2 & 0.4 & 0.2 to 1.0 \\
\hline \multicolumn{6}{|l|}{ Insulin } \\
\hline Yes & 0.05 & 0.28 & 0.9 & 1.0 & 0.6 to 1.8 \\
\hline No & -3 & - & - & - & - \\
\hline \multicolumn{6}{|l|}{$\mathrm{B}+\mathrm{C}^{4}$} \\
\hline Yes & 0.72 & 0.31 & 0.02 & 2.1 & 1.2 to 3.7 \\
\hline No & ${ }^{3}$ & - & - & - & - \\
\hline \multicolumn{6}{|l|}{ Glucose at enrollment $\geq 2.2 \mathrm{mmol} / \mathrm{L}$} \\
\hline Intercept & -0.02 & 0.20 & 0.2 & - & - \\
\hline \multicolumn{6}{|l|}{ Enrollment BHB } \\
\hline 1.2 to $2.4 \mathrm{mmol} / \mathrm{L}$ & ${ }^{3}$ & - & - & - & - \\
\hline$>2.4 \mathrm{mmol} / \mathrm{L}$ & -0.67 & 0.29 & 0.02 & 0.5 & 0.3 to 0.9 \\
\hline \multicolumn{6}{|l|}{ DIM at enrollment } \\
\hline $3-5 \mathrm{~d}$ & -0.42 & 0.17 & 0.01 & 0.7 & 0.5 to 0.9 \\
\hline $6-16 \mathrm{~d}$ & $\underline{3}^{3}$ & - & - & - & - \\
\hline \multicolumn{6}{|l|}{ Parity } \\
\hline 1 & $\underline{3}^{3}$ & - & - & - & - \\
\hline 2 & -0.46 & 0.17 & 0.01 & 0.6 & 0.4 to 0.9 \\
\hline $3+$ & -0.49 & 0.16 & 0.01 & 0.6 & 0.4 to 0.8 \\
\hline \multicolumn{6}{|l|}{ Insulin } \\
\hline Yes & -0.005 & 0.14 & 0.9 & 1.0 & 0.8 to 1.3 \\
\hline No & -3 & - & - & - & - \\
\hline \multicolumn{6}{|l|}{$\mathrm{B}+\mathrm{C}^{4}$} \\
\hline Yes & -0.03 & 0.14 & 0.3 & 1.0 & 0.7 to 1.3 \\
\hline No & -3 & - & - & - & - \\
\hline
\end{tabular}

${ }^{1}$ Ketosis was defined as blood $\mathrm{BHB} \geq 1.2 \mathrm{mmol} / \mathrm{L}$, and cure was defined as blood $\mathrm{BHB}<1.2 \mathrm{mmol} / \mathrm{L} 1 \mathrm{wk}$ after treatment.

${ }^{2} \mathrm{RR}=$ risk ratio

${ }^{3}$ Reference group.

${ }^{4} 10 \%$ butaphosphan-cyanocobalamin (Catosal, Bayer, Shawnee, KS).

$(P=0.3)$, and insulin treatment led to a significant decrease in production $(-2.3 \mathrm{~kg} / \mathrm{d})$ in those animals $(P=0.03)$. Again, early enrollment, enrollment BHB $>2.4 \mathrm{mmol} / \mathrm{L}$, and month of calving later in the year were all associated with decreased average daily milk production $(P<0.0001)$.

\section{DISCUSSION}

The objective of this study was to evaluate the therapeutic effects of insulin and $\mathrm{B}+\mathrm{C}$, with concurrent PG treatment, for ketosis. This is the first large-scale, multi-herd, randomized, blinded clinical trial that has used either of these products for treatment of ketosis. Although no difference in ketosis cure or blood BHB concentrations was observed with insulin treatment, the effect of insulin on milk production in the first $30 \mathrm{~d}$ after treatment suggests it may be useful in some animals. Analysis of $\mathrm{B}+\mathrm{C}$ suggests that it may be useful for ketosis cure and milk production in animals with low blood glucose at enrollment, especially in cows in their third or greater lactation. It should be emphasized that no animals in our trial were left completely untreated. All animals were given a 3 - $d$ treatment regimen of $\mathrm{PG}$ due to the documented benefits of PG treatment and the well-established effects of untreated ketosis (McArt et al., 2011, 2012a). Thus, we are assuming that PG treatment afforded the same benefits to all enrolled animals and we are examining the additional benefits of $\mathrm{B}+\mathrm{C}$ or insulin. Based on this study, it is not possible to comment on the efficacy of either product in the absence of PG treatment.

The ketosis incidence in this study was consistent with several published studies (Duffield et al., 1998; 
Table 6. Final model for milk production $(\mathrm{kg} / \mathrm{d})$ in the first $30 \mathrm{~d}$ after treatment for 57 first lactation Holstein dairy cows from one herd ${ }^{1}$

\begin{tabular}{|c|c|c|c|c|}
\hline Variable & Milk difference per day $(\mathrm{kg})$ & $\mathrm{SE}$ & $P$-value & $95 \% \mathrm{CI}$ \\
\hline \multicolumn{5}{|c|}{ DIM at enrollment } \\
\hline 3 to $5 \mathrm{~d}$ & -2.7 & 0.72 & 0.0005 & -4.1 to -1.2 \\
\hline 6 to $16 \mathrm{~d}$ & $-^{2}$ & - & - & - \\
\hline \multicolumn{5}{|c|}{ Month of calving } \\
\hline May & $-^{2}$ & - & - & - \\
\hline June & -1.2 & 1.0 & 0.2 & -3.2 to 0.8 \\
\hline July & -3.1 & 0.88 & 0.0006 & -4.9 to -1.4 \\
\hline August & -3.9 & 1.0 & 0.0006 & -5.9 to -1.8 \\
\hline \multicolumn{5}{|l|}{ Insulin } \\
\hline Yes & 3.8 & 0.84 & 0.002 & 2.1 to 5.5 \\
\hline No & $-^{2}$ & - & - & - \\
\hline \multicolumn{5}{|l|}{$\mathrm{B}+\mathrm{C}$} \\
\hline Yes & 0.8 & 0.63 & 0.5 & -1.4 to 2.9 \\
\hline No & $-^{2}$ & - & - & - \\
\hline
\end{tabular}

${ }^{1}$ Animals were randomly assigned to treatment with $10 \%$ butaphosphan-cyanocobalamin (B+C, Catosal, Bayer, Shawnee, KS; $\mathrm{n}=13)$, insulin $(\mathrm{n}=15), \mathrm{B}+\mathrm{C}$ and insulin $(\mathrm{n}=14)$, or control $(\mathrm{n}=15)$ at ketosis diagnosis between 3 and 16 DIM. Ketosis was defined as blood $\mathrm{BHB} \geq 1.2 \mathrm{mmol} / \mathrm{L}$.

${ }^{2}$ Reference group.

McArt et al., 2011). Though the expected risk used to calculate sample size was well below that seen in this and other studies, the risk used was conservative to ensure adequate numbers of animals were treated to analyze the effects of treatment. The variation in ketosis incidence among herds was expected (Duffield, 2000; McArt et al., 2011) and illustrates the differences in disease risk among herds.

\section{Insulin Study}

Insulin had no effect on ketosis cure, maintenance of ketosis cure, or blood BHB concentrations at 1 or 2 wk posttreatment. This is in agreement with one study (Seifi et al., 2007), but not others (Robertson, 1966; Sakai et al., 1993). Studies that have shown a benefit of insulin administration have generally had short followup periods ( $5 \mathrm{~d}$ or less). Our first follow-up test was 7 d after treatment, so our protocol may have failed to identify short-term benefits of insulin treatment. Insulin works by suppressing fat mobilization. This may be useful in animals where gluconeogenesis and ketogenesis are maximized and excess fat is accumulated in the liver (Herdt, 2000). However, in animals where gluconeogenesis is not maximized, administration of insulin may exacerbate the problem. These animals will still have

Table 7. Stratum-specific model for milk production $(\mathrm{kg} / \mathrm{d})$ in the first $30 \mathrm{~d}$ after treatment for 154 third or greater lactation Holstein dairy cows from one herd ${ }^{1}$

\begin{tabular}{|c|c|c|c|c|}
\hline Variable & Milk difference per day $(\mathrm{kg})$ & $\mathrm{SE}$ & $P$-value & $95 \% \mathrm{CI}$ \\
\hline \multicolumn{5}{|c|}{ Enrollment glucose $<2.2 \mathrm{mmol} / \mathrm{L}$} \\
\hline \multicolumn{5}{|c|}{ Insulin } \\
\hline Yes & 4.2 & 1.4 & 0.0003 & 1.4 to 7.1 \\
\hline No & -2 & - & - & - \\
\hline \multicolumn{5}{|l|}{$\mathrm{B}+\mathrm{C}$} \\
\hline Yes & 2.8 & 0.97 & 0.05 & 0.9 to 4.7 \\
\hline No & $-^{2}$ & - & - & - \\
\hline \multicolumn{5}{|c|}{ Enrollment glucose $\geq 2.2 \mathrm{mmol} / \mathrm{L}$} \\
\hline \multicolumn{5}{|c|}{$\begin{array}{l}\text { Insulin } \\
\text { Int }\end{array}$} \\
\hline Yes & -2.3 & 1.0 & 0.03 & -4.4 to -0.3 \\
\hline No & $--^{2}$ & - & - & - \\
\hline \multicolumn{5}{|l|}{$\mathrm{B}+\mathrm{C}$} \\
\hline Yes & 1.0 & 0.98 & 0.3 & -0.9 to 2.9 \\
\hline No & $-^{2}$ & - & - & - \\
\hline
\end{tabular}

${ }^{1}$ Animals were randomly assigned to treatment with $10 \%$ butaphosphan-cyanocobalamin (B+C, Catosal, Bayer, Shawnee, KS; $\mathrm{n}=48)$, insulin $(\mathrm{n}=51)$, or control $(\mathrm{n}=55)$. Animals treated with both treatments were excluded, and each treatment was compared with the control group. Ketosis was defined as blood BHB $\geq 1.2 \mathrm{mmol} / \mathrm{L}$. Blood glucose was divided into $\geq 2.2$ and $<2.2 \mathrm{mmol} / \mathrm{L}$ (low) groups.

${ }^{2}$ Reference group. 
a strong intrinsic drive for milk production and correspondingly high glucose requirements. Administration of insulin to these animals may temporarily decrease fat mobilization, further decrease body glucose levels, and lead to a subsequent increase in fat mobilization due to low blood glucose levels. We did not measure fat content of the liver in our study. However, the fact that about $40 \%$ of animals were hypoglycemic $[<2.2$ $\mathrm{mmol} / \mathrm{L}$, based on reference ranges for healthy cows (Quiroz-Rocha et al., 2009)] and none of the animals were hyperglycemic $(>5.5 \mathrm{mmol} / \mathrm{L})$ suggests that gluconeogenesis may not be maximally stimulated in most animals in the study.

Multiparous cows were less likely to cure, to maintain cure, and had increased blood BHB concentrations at 1 and 2 wk posttreatment. This is not surprising as older cows are more likely to become ketotic (Gröhn et al., 1989; Rasmussen et al., 1999), likely due to higher milk yield (Andersson and Emanuelson, 1985; Gröhn et al., 1989; Hardeng and Edge, 2001).

The relationship between higher blood BHB concentration at enrollment and decreased cure risk and increased blood BHB concentrations 1 and 2 wk after treatment is also expected. Higher concentrations of blood ketone bodies likely reflect greater difficulty adapting to lactation and these animals will take more time to adjust. Also, if treatment decreased blood BHB concentrations by the same numeric amount in all animals, animals that were more severely affected would be less likely to have BHB reduced to $<1.2 \mathrm{mmol} / \mathrm{L}$.

The relationship between low blood glucose at diagnosis and ketosis cure and blood BHB concentrations at 1 and 2 wk posttreatment is novel. We expect animals with high blood BHB to have low blood glucose (Zarrin et al., 2013). It has been suggested that animals with high blood ketone and low blood glucose concentrations have maximally stimulated gluconeogenic pathways, but glucose precursors are insufficient to meet the glucose demands of high production (Holtenius and Holtenius, 1996). Limitations on gluconeogenesis provide a defense mechanism to prevent excessive breakdown of body protein stores (Holtenius and Holtenius, 1996). It would follow that cows afflicted with this type of ketosis during a period when milk production is still increasing would remain ketotic for longer periods, as glucose demands would continue to increase with increasing milk production. However, it has been suggested that these animals are also hypoinsulinemic (Holtenius and Holtenius, 1996). Treatment with insulin should help alleviate some of the symptoms in these animals, but no effects of treatment on ketosis cure or blood BHB concentrations were realized in this study. Again, it may be that the effects of the insulin treatment are short-term and the weekly follow-up did not allow for observation of any effects. Unfortunately, more frequent follow-up was not possible in this study due to study design and labor constraints.

\section{Full Trial}

In the full trial, not only were blood glucose concentrations at enrollment significantly associated with ketosis cure risk, but there was also a significant interaction between blood glucose concentrations and $\mathrm{B}+\mathrm{C}$ treatment. Though $\mathrm{B}+\mathrm{C}$ treatment had no effect in animals with blood glucose $\geq 2.2 \mathrm{mmol} / \mathrm{L}$ at enrollment, animals with blood glucose $<2.2 \mathrm{mmol} / \mathrm{L}$ at enrollment were 2 times more likely to be cured than nontreated animals. Though a mechanism for this is unclear, it has been hypothesized that $\mathrm{B}+\mathrm{C}$ stimulates gluconeogenesis (Rollin et al., 2010). Recent work has found that $\mathrm{B}+\mathrm{C}$ increases liver mRNA expression of LXR $\alpha$, a key messenger in lipid metabolism, and stimulates the citric acid cycle (Nuber et al., 2016). Animals with low blood glucose would be more likely to respond to stimulation of these pathways, where animals with normal blood glucose would not have a strong homeorhetic drive to increase glucose production. In animals where glucose precursors were limited, gluconeogenesis would be limited due to the need to preserve lean body mass (Holtenius and Holtenius, 1996). However, in animals with impaired gluconeogenesis due to fat accumulation in the liver, stimulation of gluconeogenesis may result in decreased fat catabolism and decreased ketogenesis (Herdt, 2000). Low blood glucose at enrollment was also associated with higher blood BHB concentrations at $2 \mathrm{wk}$ posttreatment, similar to the observations in the insulin treatment trial.

Probability of cure was decreased and posttreatment blood BHB concentrations were increased for older animals and animals with high blood BHB concentrations at enrollment. The reasons for these findings have been discussed previously. Animals that were enrolled at 3 to 5 DIM were 0.6 times as likely to be cured as animals that were enrolled over the following $11 \mathrm{~d}$. This suggests that animals that are diagnosed closer to calving are more severely affected than animals that are diagnosed later in lactation, even accounting for BHB concentration at diagnosis. Animals that are diagnosed in the first few days after calving are likely experiencing effects that started during the dry period and may be more likely to develop fatty liver (Herdt, 2000). It is interesting to note that no significant differences were observed when enrollment was categorized as wk 1 (3 to 9 DIM) versus wk 2 (10 to 16 DIM) of the study. This suggests that this difference in severity of the effects 
of ketosis lasts for a short time after calving. Increased risk of worse outcomes in animals diagnosed with ketosis in the first few days of lactation has been reported previously (McArt et al., 2012b).

Average daily milk yield for $30 \mathrm{~d}$ after treatment was decreased in animals that were enrolled in the first 3 to $5 \mathrm{~d}$ of lactation in all lactation groups. This translated to decreases of $2.7 \mathrm{~kg} / \mathrm{d}(95 \% \mathrm{CI}=-4.1$ to -1.2$), 7.2$ $\mathrm{kg} / \mathrm{d}(95 \%$ CI $=-7.8$ to -3.9$)$, and $5.8 \mathrm{~kg} / \mathrm{d}(95 \%$ $\mathrm{CI}=-7.0$ to -4.7$)$ in first, second, and third and higher lactation, respectively. Thus not only does early diagnosis affect ketosis cure risk, but this carries over into effects on production. The difference in the effect of ketosis on production seen in first lactation animals is in agreement with findings of another recent study (McArt et al., 2012b). However, the decrease observed in second and greater lactation animals in the present study is much greater than that found in the previous study. McArt et al. (2012b) did not separate study animals by lactation group, so this may explain some of the difference.

Milk production was also decreased in mature (lactation 2 and higher) animals that had enrollment BHB concentrations above $2.4 \mathrm{mmol} / \mathrm{L}$. The association between high blood BHB concentrations and short-term milk yield has been well established (Duffield et al., 2009; McArt et al., 2012b). McArt et al. (2012b) found that for each $0.1 \mathrm{mmol} / \mathrm{L}$ increase in BHB above 1.2 $\mathrm{mmol} / \mathrm{L}$ at ketosis diagnosis, milk production decreased by $0.5 \mathrm{~kg} / \mathrm{d}$ in the first $30 \mathrm{~d}$ of lactation. Thus, at 2.4 $\mathrm{mmol} / \mathrm{L}$ of BHB, milk production would be decreased by $6 \mathrm{~kg} / \mathrm{d}$, which is consistent with the results of this study. It is unclear why this same effect was not seen in first lactation animals in the present study, though it may be due to lack of significant power to detect a difference.

Treatment had no significant effect on early lactation milk production in second lactation animals $(P$ $=0.5$ for both treatments). Treatment with insulin significantly increased milk production in primiparous animals $(3.8 \mathrm{~kg} / \mathrm{d}, 95 \% \mathrm{CI}=2.1$ to 5.5$)$. Though the reason for this difference is unclear, it may be that there was insufficient power to detect a treatment effect in second lactation animals or it may be due to a difference in the type of ketosis that is experienced in first lactation animals compared with older animals. Ketosis incidence in first lactation animals is generally low. Most animals in their first lactation do not have sufficient levels of production to develop ketosis due to production alone. However, animals with increased body condition at calving or decreased DMI around calving are at risk of ketosis development (Rasmussen et al., 1999; Gillund et al., 2001; Hayirli and Grummer, 2004). Measurement of BCS and differences between animals in various lactations may help explain some of this difference, which was a limitation in this study.

Both treatments significantly increased milk production in animals in their third and greater lactation, but only in cows that had low blood glucose at enrollment. Treatment with $\mathrm{B}+\mathrm{C}$ increased milk production by 2.8 $\mathrm{kg} / \mathrm{d}$ in animals with blood glucose levels $<2.2 \mathrm{mmol} / \mathrm{L}$ at enrollment, whereas treatment in animals with blood glucose $\geq 2.2 \mathrm{mmol} / \mathrm{L}$ did not have a significant effect on production. Again, if $\mathrm{B}+\mathrm{C}$ stimulates gluconeogenesis, it may be more likely to do so in animals that have low blood glucose concentrations. Increased blood glucose would likely increase milk production, as glucose is often limiting in ruminant animals (Herdt, 2000). Recent studies have found that supplementation of vitamin $\mathrm{B}_{12}$ increases blood glucose and milk production (Preynat et al., 2009a,b). However, it should be noted that vitamin $\mathrm{B}_{12}$ was given in conjunction with folic acid in those studies, so the effect of vitamin $\mathrm{B}_{12}$ alone is unknown. Also, the dose of vitamin $\mathrm{B}_{12}$ given in the current study was $1.25 \mathrm{mg}$ per injection, for a total dose of $3.75 \mathrm{mg}$ over $3 \mathrm{~d}$. This is much lower than the $10 \mathrm{mg}$ weekly dose administered by Preynat et al. (2009a,b). When $\mathrm{B}+\mathrm{C}$ was given to subclinically ketotic cows at the same dose as the present study, effects of lipid metabolism through changes in liver mRNA were observed, but no effects on blood glucose were noted (Nuber et al., 2016). However, the cows in the study by Nuber et al. (2016) were not treated with PG, so did not have the benefit of this glucose precursor. More research is required to understand the mechanism of action of $\mathrm{B}+\mathrm{C}$ and the relationship of this mechanism with blood glucose levels. Based on the results of this study, administration of $\mathrm{B}+\mathrm{C}$ to animals with low $(<2.2 \mathrm{mmol} / \mathrm{L})$ blood glucose levels at enrollment ( $40 \%$ of ketotic cows in this study) may help with ketosis cure and increase milk production in third or greater lactation animals. Though no adverse effects were observed of treatment in animals with blood glucose $\geq 2.2 \mathrm{mmol} / \mathrm{L}$ at enrollment, $\mathrm{B}+\mathrm{C}$ treatment did not show any benefit.

Insulin also significantly increased milk production by $4.3 \mathrm{~kg} / \mathrm{d}$ in animals with low blood glucose concentrations at enrollment. However, in animals with blood glucose $>2.2 \mathrm{mmol} / \mathrm{L}$ at enrollment, insulin led to a decrease in production of $2.3 \mathrm{~kg} / \mathrm{d}$. Animals with low blood glucose may have decreased circulating insulin (Holtenius and Holtenius, 1996). These animals may benefit from insulin administration to decrease ketogenesis and fat catabolism. However, it is unclear how this would increase milk production.

There is a mechanism that might explain why cows with blood glucose $>2.2 \mathrm{mmol} / \mathrm{L}$ may respond with a decrease in production. Cut points associated with de- 
fining ketosis are based on average responses and may not be valid for all animals. Some animals that are classified as ketotic, especially at the lower end of the range of blood BHB concentrations, are likely able to cope well with the increase in blood ketones as a normal component of their own adaptive response to negative energy balance. These animals have no problems with homeorhetic mechanisms; it is just that their individual cut points for abnormal ketone concentrations are higher. These cows are utilizing body fat stores to help support high levels of milk production and are often the higher producing cows in the herd (Andersson, 1984). Decreasing catabolism in these animals would actually limit production without any positive effects on health, which may explain some of the difference observed in this study. Animals with high insulin levels and insulin resistance may show no benefit from additional insulin administration. Measurement of blood insulin levels, insulin resistance, and liver fat content may help in understanding of the mechanisms involved in the loss of production seen in animals with blood glucose levels $>2.2 \mathrm{mmol} / \mathrm{L}$ at the time of enrollment. Whatever the mechanism is, based on the results of this study, treatment with glargine insulin in mature (third lactation and greater) animals should be considered if their blood glucose at ketosis diagnosis is $<2.2 \mathrm{mmol} / \mathrm{L}$ and care should be taken when treating animals with blood glucose $\geq 2.2 \mathrm{mmol} / \mathrm{L}$.

\section{CONCLUSIONS}

Blood glucose concentrations at ketosis diagnosis may be an important predictor of cure of subclinical ketosis and early lactation milk production. Variations in blood glucose concentrations may also be useful in determining an appropriate treatment regimen for ketotic animals. Use of 200 IU of glargine insulin subcutaneously once had no effect on ketosis cure, but may increase early lactation milk production in first lactation animals when given with PG. Glargine insulin may also increase milk production in mature animals with low blood glucose concentrations at ketosis diagnosis when given with PG, but should be avoided in animals with blood glucose concentrations $\geq 2.2 \mathrm{mmol} / \mathrm{L}$ due to decreases in milk production. Butaphosphan-cyanocobalamin may be beneficial when given with PG for ketosis cure in all animals and for early lactation milk production in mature animals with low blood glucose concentrations at the time of ketosis diagnosis. More research is required to examine the relationship between blood glucose concentrations and the effects of elevated blood ketone body concentrations.

\section{ACKNOWLEDGMENTS}

Funding and in-kind support for this project were provided by Ontario Ministry of Agriculture and Food (Guelph, ON, Canada), Bayer Animal Health (Shawnee, KS), Vetoquinol (Lavaltrie, QC, Canada), and the American Association of Bovine Practitioners Research Assistantship (Auburn, AL). The authors thank David Renaud, Jennifer Reynen, Robyn Thompson, Amy Thomson, and Brett Gamble of the Ontario Veterinary College (Guelph, ON, Canada), and Stephanie Ross of Michigan State University (East Lansing) for their assistance with data collection as well as the participating herd owners and managers.

\section{REFERENCES}

Akins, M. S., S. J. Bertics, M. T. Socha, and R. D. Shaver. 2013. Effects of cobalt supplementation and vitamin $\mathrm{B}(12)$ injections on lactation performance and metabolism of Holstein dairy cows. J. Dairy Sci. 96:1755-1768.

Andersson, L. 1984. Concentrations of blood and milk ketone bodies, blood isopropanol and plasma glucose in dairy cows in relation to the degree of hyperketonaemia and clinical signs. Zentralbl. Veterinarmed. A 31:683-693.

Andersson, L., and U. Emanuelson. 1985. An epidemiological study of hyperketonaemia in Swedish dairy cows; determinants and the relation to fertility. Prev. Vet. Med. 3:449-462.

Bauman, D. E., and W. B. Currie. 1980. Partitioning of nutrients during pregnancy and lactation: A review of mechanisms involving homeostasis and homeorhesis. J. Dairy Sci. 63:1514-1529.

Duffield, T. F. 2000. Subclinical ketosis in lactating dairy cattle. Vet. Clin. North Am. Food Anim. Pract. 16:231-253.

Duffield, T. F., K. D. Lissemore, B. W. McBride, and K. E. Leslie. 2009. Impact of hyperketonemia in early lactation dairy cows on health and production. J. Dairy Sci. 92:571-580.

Duffield, T. F., D. Sandals, K. E. Leslie, K. Lissemore, B. W. McBride, J. H. Lumsden, P. Dick, and R. Bagg. 1998. Physiology and management. Efficacy of monensin for the prevention of subclinical ketosis in lactating dairy cows. J. Dairy Sci. 81:2866-2873.

Fürll, M., A. Deniz, B. Westphal, C. Illing, and P. D. Constable. 2010. Effect of multiple intravenous injections of butaphosphan and cyanocobalamin on the metabolism of periparturient dairy cows. J. Dairy Sci. 93:4155-4164.

Gillund, P., O. Reksen, Y. T. Gröhn, and K. Karlberg. 2001. Body condition related to ketosis and reproductive performance in Norwegian dairy cows. J. Dairy Sci. 84:1390-1396.

Girard, C. L., and J. J. Matte. 2005. Effects of intramuscular injections of vitamin $\mathrm{B}_{12}$ on lactation performance of dairy cows fed dietary supplements of folic acid and rumen-protected methionine. J. Dairy Sci. 88:671-676.

Gröhn, Y. T., H. N. Erb, C. E. McCulloch, and H. S. Saloniemi. 1989. Epidemiology of metabolic disorders in dairy cattle: association among host characteristics, disease and production. J. Dairy Sci. 72:1876-1885.

Hardeng, F., and V. L. Edge. 2001. Mastitis, ketosis, and milk fever in 31 organic and 93 conventional Norwegian dairy herds. J. Dairy Sci. 84:2673-2679.

Hayirli, A. 2006. The role of exogenous insulin in the complex of hepatic lipidosis and ketosis associated with insulin resistance phenomenon in postpartum dairy cattle. Vet. Res. Commun. 30:749-774.

Hayirli, A., and R. R. Grummer. 2004. Factors affecting dry matter intake prepartum in relationship to etiology of peripartum lipid-related metabolic disorders: A review. Can. J. Anim. Sci. 84:337-347.

Herdt, T. H. 2000. Ruminant adaptation to negative energy balance. Vet. Clin. North Am. Food Anim. Pract. 16:215-230. 
Holtenius, P., and K. Holtenius. 1996. New aspects of ketone bodies in energy metabolism of dairy cows: A review. J. Vet. Med. A 43:579.

Iwersen, M., U. Falkenberg, R. Voigtsberger, D. Forderung, and W. Heuwieser. 2009. Evaluation of an electronic cowside test to detect subclinical ketosis in dairy cows. J. Dairy Sci. 92:2618-2624.

Kennedy, D. G., A. Cannavan, A. Molloy, F. O'Harte, S. M. Taylor, S. Kennedy, and W. J. Blanchflower. 1990. Methylmalonyl-CoA mutase (EC 5.4.99.2) and methionine synthetase (EC 2.1.1.13) in the tissues of cobalt-vitamin 12 deficient sheep. Br. J. Nutr. 64:721-732.

Kincaid, R. L., and M. T. Socha. 2007. Effect of cobalt supplementation during late gestation and early lactation on milk and serum measures. J. Dairy Sci. 90:1880-1886.

Lohr, B., B. Brunner, H. Janowitz, M. Hummel, T. Seeger, I. Weber, T. Wittek, B. Schmidt, and K. Hellmann. 2006. Clinical efficacy of Catosal ${ }^{\circledR}$ in the treatment of ketosis in cows with left abomasal displacement. Tierarztl. Umsch. 61:187-190.

McArt, J. A., D. V. Nydam, and G. R. Oetzel. 2012a. A field trial on the effect of propylene glycol on displaced abomasum, removal from herd, and reproduction in fresh cows diagnosed with subclinical ketosis. J. Dairy Sci. 95:2505-2512.

McArt, J. A., D. V. Nydam, and G. R. Oetzel. 2012b. Epidemiology of subclinical ketosis in early lactation dairy cattle. J. Dairy Sci. 95:5056-5066.

McArt, J. A., D. V. Nydam, P. A. Ospina, and G. R. Oetzel. 2011. A field trial on the effect of propylene glycol on milk yield and resolution of ketosis in fresh cows diagnosed with subclinical ketosis. J. Dairy Sci. 94:6011-6020.

Nuber, U., H. A. van Dorland, and R. M. Bruckmaier. 2016. Effects of butafosfan with and without cyanocobalamin on the metabolism of early lactating cows with subclinical ketosis. J. Anim. Physiol. Anim. Nutr. (Berl.) 100:146-155.

Ospina, P. A., D. V. Nydam, and T. J. DiCiccio. 2012. Technical note: The risk ratio, an alternative to the odds ratio for estimating the association between multiple risk factors and a dichotomous outcome. J. Dairy Sci. 95:2576-2584.

Preynat, A., H. Lapierre, M. C. Thivierge, M. F. Palin, J. J. Matte, A. Desrochers, and C. L. Girard. 2009a. Effects of supplements of folic acid, vitamin $\mathrm{B}_{12}$, and rumen-protected methionine on whole body metabolism of methionine and glucose in lactating dairy cows. J. Dairy Sci. 92:677-689.
Preynat, A., H. Lapierre, M. C. Thivierge, M. F. Palin, J. J. Matte, A. Desrochers, and C. L. Girard. 2009b. Influence of methionine supply on the response of lactational performance of dairy cows to supplementary folic acid and vitamin $\mathrm{B}_{12}$. J. Dairy Sci. 92:16851695.

Quiroz-Rocha, G. F., S. J. LeBlanc, T. F. Duffield, D. Wood, K. E. Leslie, and R. M. Jacobs. 2009. Reference limits for biochemical and hematological analytes of dairy cows one week before and one week after parturition. Can. Vet. J. 50:383-388.

Rasmussen, L. K., B. L. Nielsen, J. E. Pryce, T. T. Mottram, and R. F. Veerkamp. 1999. Risk factors associated with the incidence of ketosis in dairy cows. Anim. Sci. 68:379-386.

Robertson, J. M. 1966. The evaluation of a therapeutic trial on bovine ketosis. J. Am. Vet. Med. Assoc. 149:1620-1623.

Rollin, E., R. D. Berghaus, P. Rapnicki, S. M. Godden, and M. W. Overton. 2010. The effect of injectable butaphosphan and cyanocobalamin on postpartum serum beta-hydroxybutyrate, calcium, and phosphorus concentrations in dairy cattle. J. Dairy Sci. 93:978-987.

Sakai, T., T. Hayakawa, M. Hamakawa, K. Ogura, and S. Kubo. 1993. Therapeutic effects of simultaneous use of dextrose and insulin in ketotic dairy cows. J. Dairy Sci. 76:109-114.

Seifi, H. A., S. J. LeBlanc, E. Vernooy, K. E. Leslie, and T. F. Duffield. 2007. Effect of isoflupredone acetate with or without insulin on energy metabolism, reproduction, milk production, and health in dairy cows in early lactation. J. Dairy Sci. 90:4181-4191.

Weber, C.. C. T. Schaff, U. Kautzsch, S. Borner, S. Erdmann, S. Gors, M. Rontgen, H. Sauerwein, R. M. Bruckmaier, C. C. Metges, B. Kuhla, and H. M. Hammon. 2016. Insulin-dependent glucose metabolism in dairy cows with variable fat mobilization around calving. J. Dairy Sci. 99:6665-6679.

Wittrock, J. A., T. F. Duffield, and S. J. LeBlanc. 2013. Short communication: Validation of a point-of-care glucometer for use in dairy cows. J. Dairy Sci. 96:4514-4518.

Zarrin, M., L. De Matteis, M. C. M. B. Vernay, O. Wellnitz, H. A. van Dorland, and R. M. Bruckmaier. 2013. Long-term elevation of beta-hydroxybutyrate in dairy cows through infusion: Effects on feed intake, milk production, and metabolism. J. Dairy Sci 96:2960-2972 